\title{
IMPROVEMENT OF STAND JIG SEALER AND ITS INCREASED PRODUCTION CAPACITY
}

\author{
K. E. N Soebandrija ${ }^{1}$, S.W.D Astuti ${ }^{2}$ \\ ${ }^{1}$ Bina Nusantara University, Industrial Engineering Department, Syahdan Campus, J1. K.H. Syahdan No. 9, Palmerah, \\ Jakarta Barat 11480 Indonesia \\ ${ }^{2}$ Bina Nusantara University, Industrial Engineering Department, Syahdan Campus, JL. K.H. Syahdan No. 9, Palmerah, \\ Jakarta Barat 11480 Indonesia
}

\begin{abstract}
This paper has the objective to prove that improvement of Stand Jig Sealer can lead to the cycle time target as part of Improvement efforts and its Productivity. Prior researches through prior journals both classics journal such as Quesnay (1766) and Solow (1957) and updated journal such as Reikard (2011) researches, are mentioned and elaborated. Precisely, the research is narrowed down and specified into automotive industry and eventually the software related of SPSS and Structural Equation Modeling ( SEM). The analysis and its method are conducted through the calculation working time. The mentioned calculation are reinforced with the hypothesis test using SPSS Version 19 and involve parameters of production efficiency, productivity calculation, and the calculation of financial investments. The results obtained are augmented achievement of cycle time target $\leq 80$ seconds posterior to improvement stand jig sealer. The result from calculation of SPSS-19 version comprise the following aspects :the one-sided hypothesis test is rejection of Ho: $\mu \geq 80$ seconds, the correlation $r s=0.84$, regression $y=0.159+0.642 x$, validity $R$ table $=0.4438$, reliability value of Cronbach's alpha $=0.885>0.70$, independence (Chi Square) Asymp. Sig $=0.028<0.05,95 \%$ efficiency, increase productivity 11\%, financial analysis (NPV 2,340,596>0, PI 2.04>1, IRR $45.56 \%>i=12.68 \%$, $P P=1.86)$. The Mentioned calculation results support the hypothesis and ultimately align with the objective of this paper to prove that improvement of Stand Jig Sealer and its relation toward the cycle time target. Precisely, the improvement of production capacity of PT. Astra Daihatsu Motor.
\end{abstract}

\section{Introduction}

The background of the improvement plan in this paper refers to an increase in production capacity characterized by the acceleration of cycle time target. Precisely, the improvement is needed in company in Productivity of Corporate Management of Mcinnes (1984), and in particular in the Automotive Industry. This paper discusses the related theory and concept, that eventually is elaborated by the empirical study in one of automotive companies in Indonesia. To begin with, the improvement is needed in the Automotive Industry that is triggered by the fierce competition that require extensive effort to obtain market share. The precise research on both aspects have been elaborated by Fournier and Agard (2007) through the prior research of Womack et al (1991) that further develop the need of final product variety and complex management. Simultaneously, Miltenburg (1989) elaborated the situation of customers that require to receive product as fast as possible while obtaining competitive price.
In the empirical study of PT. Astra Honda Motor (AHM) refers to Current condition on Sub Assembly Engine Hood that is still exceeding the target with the highest current cycle time and simultaneously is still going idle time for several work processes. Therefore, there is the need to improve work processes for this area pertaining the Current Cycle Time in this empirical study. Two previous studies on the same topic is the analysis of investment feasibility infra red sensor transceiver to the endurance test in AHM and feasibility analysis of investment in production capacity of die making PT. Astra Daihatsu Motor(ADM), the mentioned method utilizes use business feasibility analysis study of the technical and financial side. However, this paper analyzes feasibility of combining business with SPPSS statistical methods and eventually SEM in order to obtain results with accurate analysis. 


\section{Literature Review}

The literature review pertaining Productivity is one of the theories and concepts that are elaborated in this paper. Tangen (2002) refers to Quesnay (1766) as the first one who introduced the terminology of Productivity, in Journal de l'Agriculture over two centuries ago. Productivity is considered as one of the basic variables governing economic production activities (Tangen, 2002). At the same time, productivity is also seen as one of the most vital factors affecting a manufacturing company's competitiveness. Thus, the view point on Competitiveness is aligned with the Introduction session as elaborated by Fournier and Agard (2007).

Reikard (2011) elaborated productivity in term of total productivity factor. Precisely, Reikard mentioned Since the pioneering work of Solow [1957], it has been recognized that a substantial share of economic growth is comprised by technical advance, and that over long periods of time, the rate of technical advance can be approximated by the production function residual. The residual, generally called total factor productivity, is of course not a perfect measure of technology, since at shorter horizons it is extremely variable.

Chinda (2010) refers to several concepts of Productivity. Precisely, Chinda (2010) mentions that Productivity is one of the most common measures of an organization's competitiveness. It has often been cited as a key factor in industrial performance, and actions to increase it are said to improve profitability and the wage earning capacity of employees (Cosmetatos and Eilon, 1983). The concept of productivity, generally defined as the relation between output and input, has been available for over 2 centuries and applied in many different circumstances on various levels of aggregation in the economic system (Jorgenson and Griliches, 1967).

Similarly, Chinda (2010) elaborated 27 Productivity Attributes that are commonly discussed:

1.Financial incentive, according to Millea and Fuess (2005); 2. Training: according to Black and Lynch (1996) and Hoffman and Mehra (1999); 3. Work pressure, according to (Siu et al., 2004) and (Black and Lynch,1996).4. Personal recognition, according to (Allender, 1984) and (Marsidi, 2009).5. Workers' attitude, according to Beck (2009) and (Marsidi, 2009).

6. Teamwork, according to (Asian Productivity Organization, 2007). 7. Knowledge background, according to Kilic and Okumus (2005) and (Barocci and Wever, 1982). 8. Workers' experience, according to Lubbe (2000) and Kilic and Okumus (2005);9. Workers' recruitment, according to Asian Productivity Organization (2007), 10. Leader's support, according to (Loke, 2001) and (Savery, 1998), 11. Job allocation, according to Bell (1988) and (Peter et al., 2007); 12. Feedback, according to Pritchard (1995) ;13. Safe workplace, according to Thailand Productivity Institute (2008b) and Sales Creators (2009); 14. Supervision, according to Bell(1988); 15. Equipment effectiveness, according to (Thailand Productivity Institute, 2008c).
16. Inventory management: According to Thailand Productivity Institute (2008a);17. Performance appraisal, according to Dessler (2005) and Thailand Productivity Institute (2008b);18. Job description, according to (Thailand Productivity Institute, 2008b); 19. Operational audit, according to Batra et al. (2009); 20. Information technology investment, according to Swierczek and Shrestha (2003) ;21. Service quality, according to (Haynes and Duvall, 1992); 22. Customer satisfaction, according to Lubbe (2000); 23. Two-way communication, according to Relgolook (2009) and Hoffman and Mehra (1999); 24. Top management commitment, according to Hoffman and Mehra (1999) ;25. Advertisement and marketing, according to Kilic and Okumus (2005); 26. Total quality management, according to (Thailand Productivity Institute, 2008b); 27. Benchmarking system, according to Hussain (2008).

\section{Research Methodology}

The method of data collection researchers directly using stop-watches, and from the results researchers testing the adequacy of the data, the uniformity of data, SPSS test, eventually SEM, and determine the efficiency, productivity of manpower, and perform financial analysis calculations.

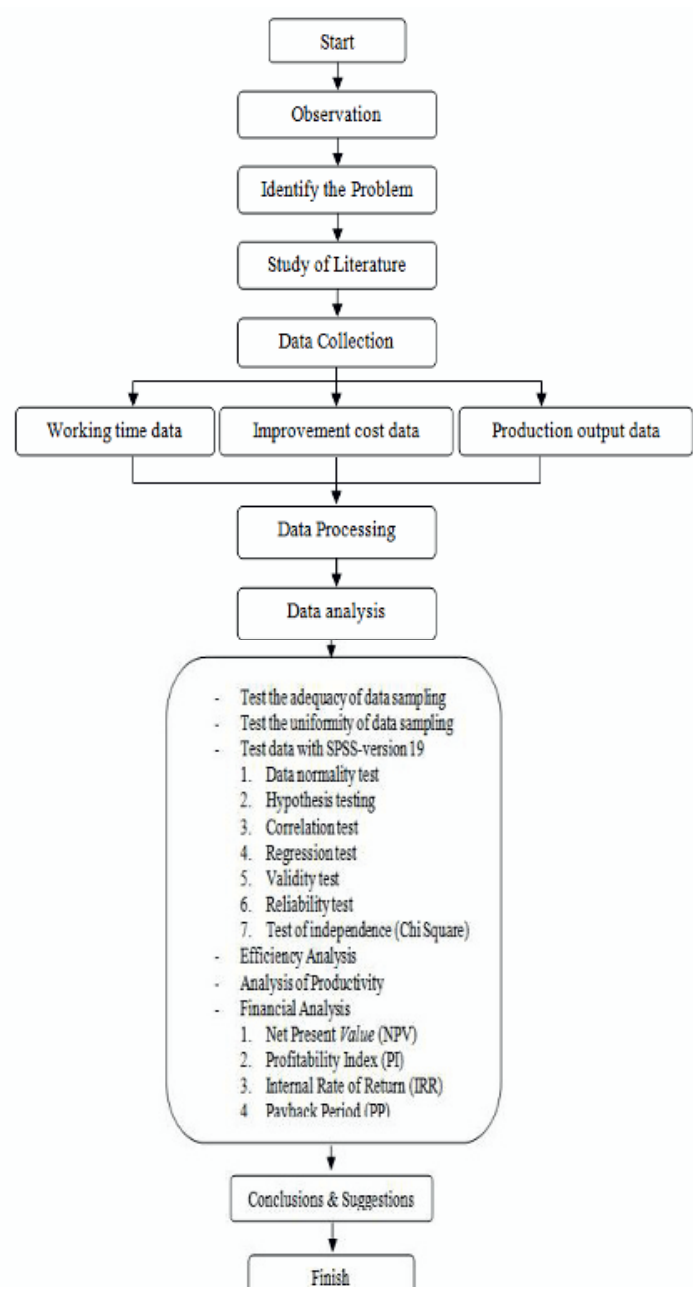

Figure 1. Flowchart of Research Methodology 


\section{Results and Analysis}

The results of cycle time after stand jig sealer improvement:

Table 1. Comparison of Working Post and Cycle Time Before and After Improvement

\begin{tabular}{|l|l|l|}
\hline & $\begin{array}{l}\text { Working Post } \\
\text { Quantity }\end{array}$ & Cycle Time \\
\hline $\begin{array}{l}\text { Before } \\
\text { Improvement }\end{array}$ & 3 Working Post & 133 Seconds \\
\hline $\begin{array}{l}\text { After } \\
\text { Improvement }\end{array}$ & 2 Working Post & 76 Seconds \\
\hline
\end{tabular}

From the results, stand jig sealer improvement helps achievement of cycle time target $\leq 80$ seconds, therefore increasing production capacity in the sub assembly engine hood can be achieved.

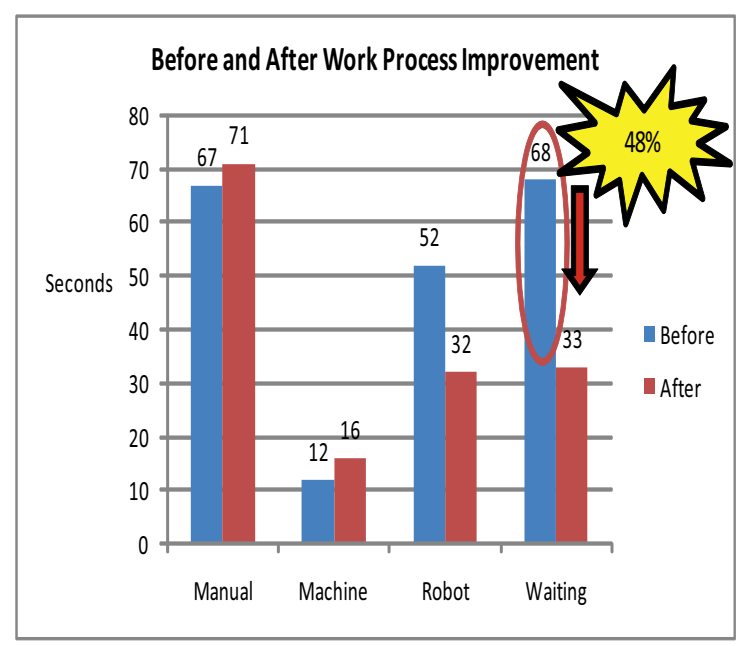

Figure 2. Graph Before and After Work Process Improvement

Figure 2 is a graph showing the comparison of working time before and after improvement. This means that stand jig sealer improvement helps to reduce waiting time $48 \%$. Here are the results of improvement tool sealer:

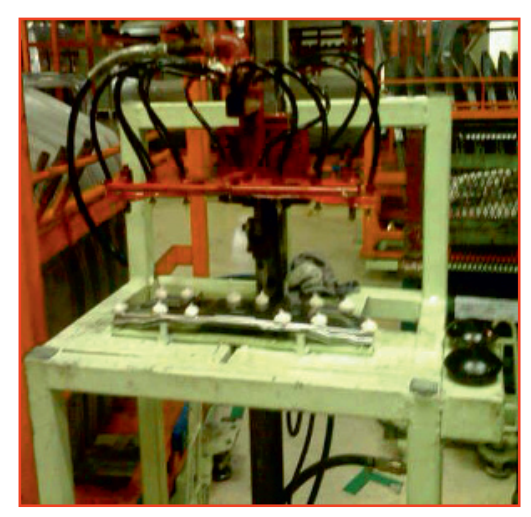

Figure 3. Improvement Stand Jig Sealer

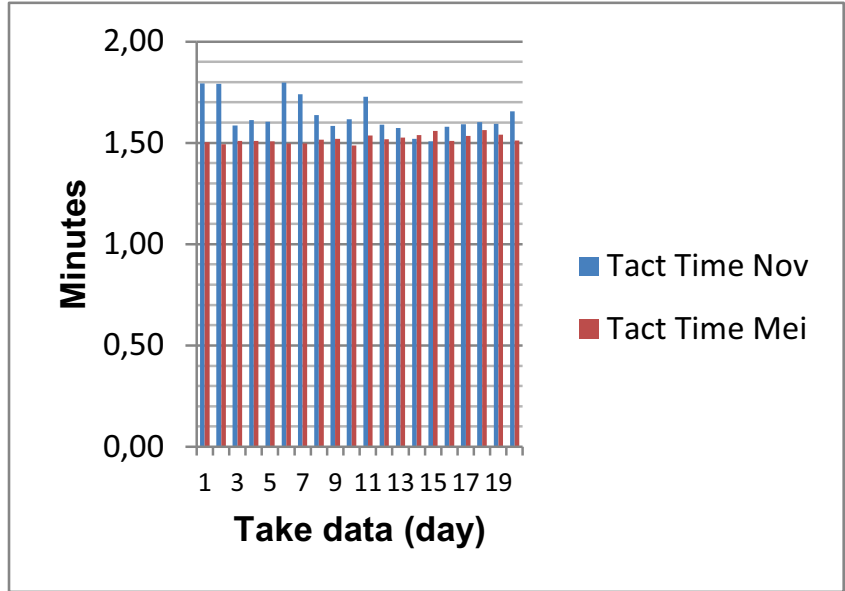

Figure 4. Graph Tact Time Production Months for May 2012 and November 2012

The graph above shows a comparison tact time production in May (before the improvement done) with Tact time production in November (after the improvement done). This is shows that stand jig sealer improvement helped decrease production time.

\section{Measurement Results of Working Time Stopwatch}

Here are the results of measurement of working time with Stopwatch (stopwatch time study) taken with a sampling of 20 times in the area of Sub Assembly Engine Hood:

\begin{tabular}{|c|c|c|c|c|c|c|c|c|c|c|c|c|c|c|c|c|c|c|c|c|c|c|c|}
\hline \multirow{2}{*}{ POS } & & \multirow{2}{*}{ Work Elemen } & \multicolumn{20}{|c|}{ Cycle Time (seconds) } & \multirow{2}{*}{ total } \\
\hline & & & 1 & 2 & 3 & 4 & 5 & 6 & 7 & 8 & 9 & 10 & 11 & 12 & & 14 & 15 & 16 & 17 & 18 & 19 & 20 & \\
\hline & & $\begin{array}{l}\text { Process sealer panel hood lock in multiple } \\
\text { sealer tools }\end{array}$ & 8 & 7 & 7 & 9 & 8 & 8 & 9 & 8 & 8 & 7 & 7 & 8 & 8 & 8 & 8 & 7 & 7 & 9 & 7 & 7 & 155 \\
\hline & & $\begin{array}{l}\text { Process setting panel hood lock in panel } \\
\text { imner engine hood jig }\end{array}$ & 6 & 7 & 7 & 7 & 7 & 6 & 6 & 7 & 7 & 7 & 7 & 7 & 7 & 7 & 6 & 8 & 7 & 7 & 6 & 6 & 135 \\
\hline & & $\begin{array}{l}\text { Processs spot welding panel hood lock in } \\
\text { panel immer engine hood }\end{array}$ & 22 & 22 & 23 & 22 & 22 & 23 & 22 & 23 & 22 & 22 & 22 & 22 & 23 & 24 & 24 & 23 & 23 & 23 & 23 & 24 & 454 \\
\hline & & ler and process & & & & & & & & & & & & & & & & & & & & & \\
\hline & & $\begin{array}{l}\text { marriage between panel immer engine hood } \\
\text { and panel outer engine hood }\end{array}$ & 39 & 39 & 39 & 38 & 39 & 38 & 39 & 39 & 39 & 39 & 39 & 39 & 39 & 39 & 39 & 39 & 39 & 39 & 39 & 39 & 778 \\
\hline \multirow{4}{*}{ POS 2} & & Process setting retainer & 15 & 15 & 15 & 14 & 14 & 14 & 14 & 15 & 14 & 15 & 15 & 15 & 15 & 15 & 15 & 15 & 15 & 15 & 15 & 15 & 295 \\
\hline & & $\begin{array}{l}\text { Proses spot welding retain } \\
\text { imner engine hood }\end{array}$ & 8 & 8 & 8 & 8 & 8 & 8 & 8 & 8 & 7 & 8 & 8 & 8 & 8 & 9 & 9 & 8 & 8 & 8 & 8 & 8 & 161 \\
\hline & & $\begin{array}{l}\text { Proses sealer panel outer engine hood at } \\
\text { robot sealer }\end{array}$ & 40 & 40 & 40 & 40 & 40 & 40 & 40 & 40 & 41 & 40 & 41 & 40 & 40 & 40 & 41 & 41 & 41 & 40 & 41 & 40 & 806 \\
\hline & 4 & $\begin{array}{l}\text { Process setting panel immer engine hood at } \\
\text { loading hemming }\end{array}$ & 13 & 13 & 13 & 14 & 14 & 14 & 13 & 13 & 13 & 13 & 14 & 14 & 14 & 13 & 14 & 13 & & 14 & 14 & 13 & 269 \\
\hline & & TOTAL & & & & & & 15 & 151 & 153 & 151 & & 153 & 153 & 154 & 155 & & $1 / 47$ & 15 & 155 & 153 & 152 & 3.053 \\
\hline
\end{tabular}

Test Data Adequacy With Stopwatch

Terms: 95\% confidence level and the degree of accuracy of $5 \%$, obtained $\mathrm{N}^{\prime}=0: 15$ time of observation. From the above calculation shows the number of observations that should be implemented ( $\left.\mathrm{N}^{\prime}\right)$ is smaller than the number of observations that have been made $(\mathrm{N}=20)$. The conclusion is the number of observations that have been carried out 20 times giving 95\% confidence level and 5\% level of accuracy. 
Table 3. Data Results using SPSS- version 19

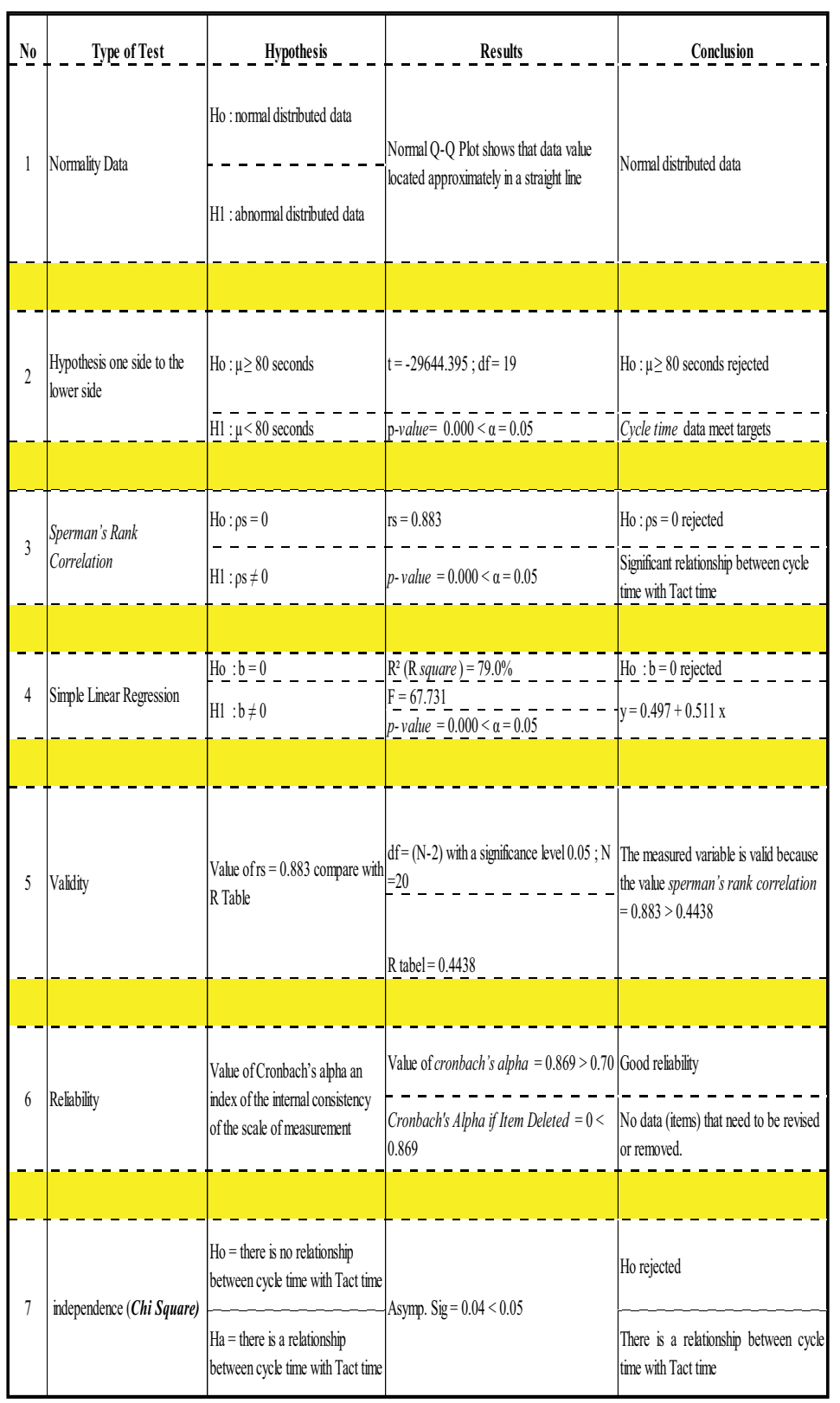

\section{Production Efficiency Calculation}

From those data, production efficiency can be calculated with Tact time $=1.51$ minutes.

Efficiency After Improvement ( November ) =

$\frac{\text { Actual Volume of Production }}{\text { Working Time/Tact Time. }}=\frac{13656}{20739 / 1.51}=99 \%$

Efficiency Before Improvement ( May ) =

$\frac{\text { Actual Volume of Production }}{\text { Working Time/Tact Time. }}=\frac{13272}{21676 / 1.51}=92 \%$

Efficiency of the calculation above, it appears that an increase in efficiency. This means that stand jig sealer improvement helps increase production efficiency.

\section{Uniformity Test Data With Stopwatch}

To know that the population sample data used has a normal balance of value - average at $95 \%$ confidence level, test results of the uniformity of data is as follows:

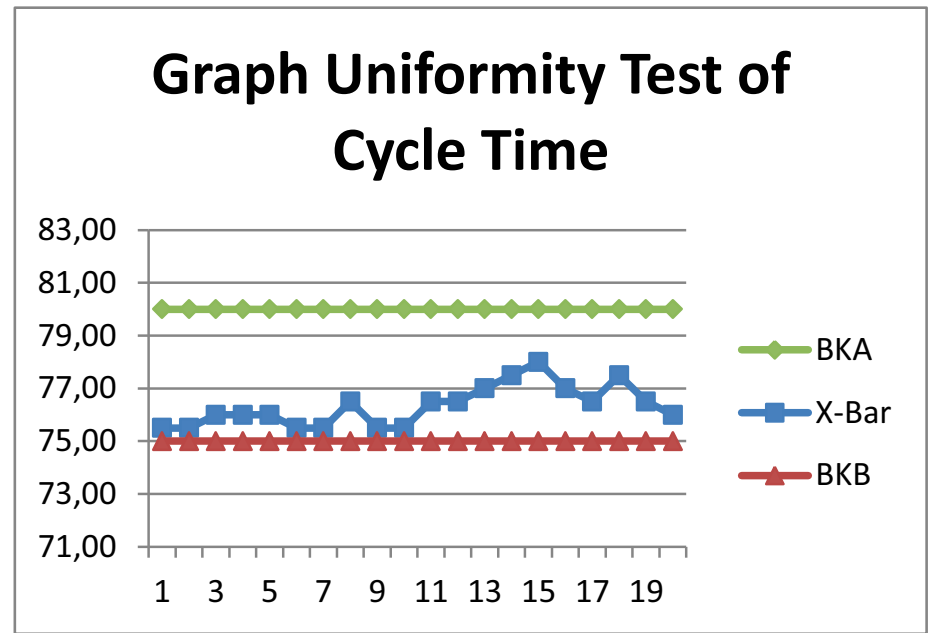

Figure 5. Uniformity Test of Cycle Time

\section{Productivity Calculation}

The calculation method to locate manpower productivity in the welding shop to compare the productivity before and after improvement:

Productivity Before

Actual Volume of Production

$\left[\frac{\text { Total of Manpower }}{2 \text { Shifts }}\right] \times$ Working Time $=$
13656
$=0.22$
$6 / 2 \times 20739$

Productivity After

Actual Volume of Production $\left[\frac{\text { Total of Manpower }}{2 \text { Shifts }}\right]^{\times \text {Working Time }}=$
13656
$=0.33$
$4 / 2 \times 20739$

From manpower productivity calculations above, the difference after and before there was an increase of $11 \%$. This means that stand jig sealer improvement can help increase the productivity of manpower. 


\section{Financial Analysis}

\section{Data of Cost Improvement}

Table 4. Cost Improvement

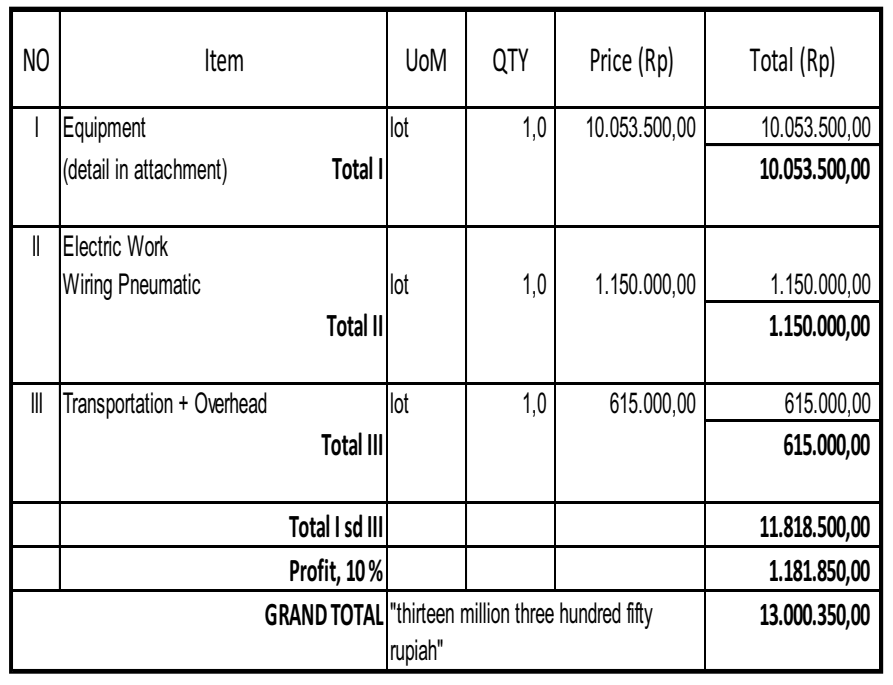

Calculate the financial analysis, it is necessary to calculate cash inflow process with compare data before and after improvement, Cash inflow of data obtained from :

Cash inflow = usage price before improvement - usage price after improvement

$$
\begin{aligned}
& =\text { Rp. } 121,142,890-\text { Rp. } 113,102,346 \\
& =\text { Rp. } 8,040,544
\end{aligned}
$$

While the data obtained from the initial investment:

- Price Equipment

: Rp. 13,000,350

- $\quad$ Price Material (sealer orotex)

: Rp.

\section{$1,738,003$}

- Energy (Electricity and water) : Rp. 208,220

- Total initial investment

: Rp. $14,946,573$

\section{Net Present Value (NPV)}

NPV is calculated for a period of 5 years with $\mathrm{i}=12.68 \%$

Table 5. Net Present Value for 5 years $(\mathrm{i}=12.68 \%)$

\begin{tabular}{|c|r|r|r|r|}
\hline Years & Investment & Cash Flow & $\begin{array}{c}\text { Discount factor } \\
(12,68 \%)\end{array}$ & $\begin{array}{r}\text { Present Value } \\
(\mathrm{PV})\end{array}$ \\
\hline 0 & $(14.946 .573)$ & - & - & $(14.946 .573)$ \\
\hline 1 & - & 8.040 .544 & 0,73 & 5.869 .597 \\
\hline 2 & - & 8.040 .544 & 0,53 & 4.261 .488 \\
\hline 3 & - & 8.040 .544 & 0.39 & 3.135 .812 \\
\hline 4 & - & 8.040 .544 & 0.29 & 2.331 .758 \\
\hline 5 & - & 8.040 .544 & 0,21 & 1.688 .514 \\
\hline
\end{tabular}

Discount factor obtained from the formula: $\mathrm{PV}=$

$$
F\left(\frac{1}{(1+i)^{n}}\right)
$$

Rate obtained from the highest interest rate at end of November 2012 obtained from www.bi.go.id (attachment) From the table calculation above, the amount obtained during the 5 -year NPV is greater than 0 or a positive NPV.

\section{Profitability Index (PI)}

Profitability Index calculation is as follows:

$\mathrm{PI}=\mathrm{TPV} / \mathrm{Io}=$

$\underline{5869597+4261488+3135812+2331758+1688514}$

14946573

$\mathrm{PI}=1.16$

From the calculation, the analysis obtained Profitability Index $(\mathrm{PI})>1$

\section{Internal Rate of Return (IRR)}

For analytical calculations Internal Rate of Return (IRR) is as follows:

Table 6. Internal Rate of Return (IRR) for 5 years

\begin{tabular}{|c|r|c|}
\hline Year & Cash Flow & Investment \\
\hline 0 & - & $(14.946 .573)$ \\
\hline 1 & 8.040 .544 & - \\
\hline 2 & 8.040 .544 & - \\
\hline 3 & 8.040 .544 & - \\
\hline 4 & 8.040 .544 & - \\
\hline 5 & 8.040 .544 & - \\
\hline
\end{tabular}

From the table above, formula to calculate IRR using Microsoft Excel is equal to $45.56 \%$. IRR calculation results in Microsoft Excel use interest rate $\mathrm{i}=12.68 \%$, because of IRR value is greater than interest rate therefore investment is feasible.

\section{Payback Period (PP)}

Analysis Payback Period calculation (PP) can be seen in the table below: 
Table 7. Payback Period (PP) for 5 years

\begin{tabular}{|c|c|c|c|}
\hline Year & Remark & Value & Remin \\
\hline 0 & Initial Investment & $14.946 .572,58$ & $14.946 .572,58$ \\
\hline 1 & Cash Flow & $8.040 .543,67$ & $6.906 .028,91$ \\
\hline 2 & Cash Flow & $8.040 .543,67$ & $(1.134 .514,75)$ \\
\hline 3 & Cash Flow & $8.040 .543,67$ & $(9.1755 .058,42)$ \\
\hline 4 & Cash Flow & $8.040,543,67$ & $(17,215,602,09)$ \\
\hline 5 & Cash Flow & $8.040 .543,67$ & $(25.556 .155,70)$ \\
\hline
\end{tabular}

$\mathrm{PP}=\mathrm{Io} / \mathrm{PV}$

$\mathrm{PP}=\frac{14946573}{8040544}=1.86$

$\mathrm{PP}=1.86$

Payback period can be achieved for 1.86 years or 1 year 9 months.

In term of empirical study in this paper, other than the literature reviews of Journals that have been mentioned in the Literature Review sessions; there are several references that are originated from other sources, including books and articles. Precisely, Imai (1999) on Gemba Kaizen, Johan (2011) on the Feasibility Study, Prastito (2004) on Statistics using SPSS, Sutalaksana et al (2000) pertaining Working Method, Umar (2009) about the Business Feasibility Study, Uyanto (2009) discussed SPSS Software, Wignjosoebroto (2008) about Ergonomics, and Wignjosoebroto (2006) on Industrial Engineering and Management.

\section{CONCLUSION}

The conclusion in this paper comprise two major aspects. The first one refers to the conclusion in term of theory and concept. The second one refers to the conclusion in term of the empirical study of one of automotive industries in Indonesia.

First, for the conclusion that refers to the theory and concept, it is indispensable to refer to the original concept of productivity as triggered by Quesnay (1766), and other classics journal including Solow (1957) and updated journal such as Reikard (2011), Chinda (2010), Womack (1991) and other related journals. Furthermore, the attention on productivity refers to the Total Productivity Factors, as relate to the economic growth, including the competitiveness that is also elaborated by Fournier and Agard (2007) through the prior research of Womack et al (1991).
Not to mention, the alignment of competitiveness and the customers requirement as indicated by Miltenburg (1989).

Finally, the conclusion of this paper refer to the 27 productivity attributes that are elaborated by Chinda (2010). Those 27 attributes are indispensable to keep track on the benefit and the focus on each company on what is or are their attributes to be focused on, based on the purpose, vision and mission of the company or other related unit of analysis.

Second, for the conclusion that refer to the empirical study; it is concluded that

- Improvement stand jig sealer helps achievement of cycle time target $\leq 80$ seconds, which means achievement of production capacity in sub assembly engine hood.

- The results of stand jig sealer improvement is reduce the waiting time of work processes as much as $48 \%$

- The results of analysis SPSS version 19 for dataworking time and production output after improvement, showing that all the criteria data meet the target cycle time $\leq 80$ seconds, valid, reliable.

- The results of production efficiency with stand jig sealer improvement is increased $7 \%$

- The productivity of manpower after stand jig sealer improvement an increase of $11 \%$

- The results calculation of the financial analysis of stand jig sealer improvement obtained:

1. Net Present Value (NPV) 2,340,597>0

2. Profitability Index (PI) $1: 16>1$

3. Internal Rate of Return (IRR) $45.56 \%>i=12.68 \%$

4. Payback Period (PP) can be achieved for 1 year 9 months

It is concluded that from the results of financial analysis, stand jig sealer application is viable. 


\section{REFERENCES}

1. Allender, M.C. (1984). Productivity Enhancement: A New Teamwork Approach. John Wiley \& Sons, New York, NY, U.S.A.

2. Asian Productivity Organization. (2006). Handbook on Green Productivity. Available from: http://www.apotokyo.org/gp/e publi/ebooks gp/ APO_Handbook_on_Productivity. pdf. Accessed date: Oct 16, 2008

3. Asian Productivity Organization. (2007). Productivity measurement. APO News, Tokyo, Japan, 37(5):1-8.

4. Barocci, T.A., and Wever, K.R. (1982). Productivity, industrial relations and human resource management: football on a soccer field. Works Paper, Sloan School of Management, Massachusetts Institute of Technology, Cambridge, Mass., USA.

5. Batra, V.K., Kumar, K., Chhangani, P.N., and Parihar, P.S. (2009). Plant Operations and Productivity Enhancement - a Case Study. Available from: http://www.holtecnet.com/ web/content/references/TechnicalPapers/ p_2004_5.pdf. Accessed date: Jun 4, 2009.

6. Black, S.E., and Lynch, L.M. (1996). Human capital investments and productivity. The American Economics Review, 86 (2), p. 263267.

7. Beck, M. (2009). Protect your Attitude. Available from: http://www.xleaders. com/articles Protect Your Attitude. pdf. Accessed date: Jun 3, 2009.

8. Bell, C.R. (1988). Human Resources and Labour Relations. American Management Association, Managing Solutions.

9. Chinda, T. (2010). Structural equation modeling of productivity enhancement. Journal of Science Technology , 17(3), p. 259-276.

10. Cosmetatos, G.P. and Eilon, S. (1983). Effects of productivity definition and measurement on Performance evaluation. European Journal of Operations Research, 14(1), p.31-35

11. Dessler, G. (2005). Human Resource Management. 10th ed. Pearson EducationInc., Upper Saddle River, NJ, USA.

12. Fournier, X., Agard, B. (2007). Improvement of earliness and lateness by postponement on an automotive production line. International Journal of Flexible Manufacturing Systems, 19, p. $107-121$

13. Haynes, R.M. and Duvall, P.K. (1992). Service quality management: a process-control approach. Int. J. Serv. Ind. Manag., 3(1):14-24.

14. Hoffman, J.M. and Mehra, S. (1999). Management leadership and productivity improvement programs. International Journal of Applied Quality Management, 2 (2), p.221-232.
15. Hussain, M.R. (2008). Striving for Organizational Excellence through Productivity Enhancement. PSMB 2008 Conference, Malaysia Productivity Corporation. Available from:http:/www.hrdnet.com.my/imejconf2008/ 5Striving.pdf. Accessed date: Jun 3, 2009.

16. Imai, M. (1999). Gemba Kaizen : Pendekatan Akal Sehat, Berbiaya Rendah Pada Manajemen. PT. Pustaka Binaman Pressindo : Jakarta

17. Johan, S. (2011). Studi Kelayakan Pengembangan Bisnis. Graha Ilmu : Yogyakarta

18. Jorgenson, D.W. and Griliches, Z. (1967). The explanation of productivity change. Review of Economics Studies, Vol. 34, No. 3, p.249-283.

19. Kilic, H. and Okumus, F. (2005). Factors influencing productivity in small island hotels: evidence from Northern Cyprus. International Journal of Contemporary Hospitality Management, 17(4):315-331.

20. Loke, C.F. (2001). Leadership behaviours: effects on job satisfaction, productivity, and organizational commitment. Journal of Nursing Management, 9(4):191-204.

21. Lubbe, B. (2000). Tourism Distribution: Managing the Travel Intermediary. Juta \& Company Limited, Cape Town, South Africa.

22. Marsidi, A. (2009). Improving Productivity through People. Malaysian Institute of Management. Available from: http://mgv.mim.edu.my/MMR/8412/841203.htm . Accessed date: Jun 3, 2009.

23. Mcinnes, J.M (1984). Corporate Management of Productivity- An Empirical Study. Strategic Management Journal, 5, p. 351-365

24. Millea, M. and Fuess, S.M. (2005). Does pay affect productivity or react to it? Examination of U.S. manufacturing. Q. Review of Economics Finance, 45, p.796-807.

25. Miltenburg J (1989) Level schedules for mixedmodel assembly lines in just-in-time production systems. Manage Sci 35, p.192-207

26. Peter, E., Matta, R., and Boe, W. (2007). Shortterm work scheduling with job assignment flexibility for a multi-fleet transport system. Eur. J. Oper. Res., 280(1):82-98.

27. Prastito, A. (2004). Cara Mudah Mengatasi Masalah Statistik dan Rancangan Percobaan dengan SPSS 12. PT. Elex Media Komputindo : Jakarta

28. Pritchard, R.D. (1995). Productivity Measurement and Improvement: Organizational Case Studies. Greenwood Publishing Group, Westport, CT, USA. 
29. Quesnay, F. (1766). Analyze de la formule arithmetique du tableau economique de la distribution des depenses annuelles d'une nation agricole. Journal de l'Agriculture, du Commerce $\&$ des Finances, p. 11-41.

30. Reikard, G. (2011). Total factor productivity and $\mathrm{R} \& \mathrm{D}$ in the production function. International Journal of Innovation and Technology Management. 8 (4), p. 601-613.

31. Savery, L.K. (1998). Management and productivity increases. Journal of Management Development, 17(1):68-74.

32. Solow, R. M. (1969). "Investment and technical change," in Arrow, K. J. (ed.), Mathematical Models in the Social Sciences, Palo Alto, CA: Stanford University Press.

33. Tangen, S.(2005). Demystifying productivity and performance. International Journal of Productivity and Performance Management, 54 (1), p. 34-46.

34. Thailand Productivity Institute. (2008a). Inventory and Human Resource Management. Availablefrom:http://www.ftpi.or.th/LinkClick.a spx? fileticket $=$ capPRV81GyQ\%3d\&tabid= 96\&mid=656. Accessed date: Jun 3, 2009.

35. Thailand Productivity Institute. (2008b). Quality Control System. Available from: http:// www.ftpi.or.th/LinkClick.aspx?fileticket $=$ AbV7AB00kAw\%3d\&tabid=96\&mid=656. Accessed date: Jun 3, 2009.

36. Thailand Productivity Institute. (2008c). Setup Time Reduction. Available from: http:// www.ftpi.or.th/LinkClick.aspx?fileticket $=$ qCRA1dzh0Xo\%3d\&tabid=96\&mid $=656$. Accessed date: Jun 3, 2009.

37. Relgolook. (2009). Productivity Enhancement Solution for Effective Email Management. Available from: http://www.articlebase. com/management-rticles/relgolookproductivityenhancement-solution-foreffectiveemail-management-800221.html. Accessed date: Jun 4, 2009.
38. Sales Creators. (2009). Better Workplace. Available from:http://www.Salescreators.com/ Section4/betterWkPlace.html. Accessed date: Jun 3, 2009.

39. Siu, O., Phillips, D.R., and Leung, T. (2004).Safety climate and safety performance among construction workers in Hong Kong: the role of psychological strains as mediators. Accident Anal. Prev., 36:359-366.

40. Sutalaksana,I.,Anggawisastra, R.,Tjakraatmadja, J. (2000). Teknik Tata Cara Kerja. Institut Teknologi Bandung : Bandung.

41. Swierczek, F.W. and Shrestha, P.K. (2003). Information technology and productivity: a comparison of Japanese and Asia-Pacific banks. The Journal of High Technology Management Research, 14(2):269-288.

42. Umar, H. (2009). Studi Kelayakan Bisnis. Gramedia Pustaka Utama : Jakarta.

43. Uyanto, S. (2009). Pedoman Analisis Data Dengan SPSS. Graha Ilmu : Yogyakarta

44. Wignjosoebroto, S. (2008). Ergonomi : Studi Gerak dan Waktu. Institut Teknologi Sepuluh Nopember : Surabaya.

45. Wignjosoebroto, S. (2006). Pengantar Teknik \& Manajemen Industri. Institut Teknologi Sepuluh Nopember : Surabaya.Womack J, Jones D, Roos D (1991) The machine that changed the World: the story of lean production. Harper Perennial, New York, NY 